\title{
Utilization of estuarine organic matter during growth and migration by juvenile brown shrimp Penaeus aztecus in a South Texas estuary
}

\author{
P. Riera ${ }^{1, *}$, P. A. Montagna ${ }^{2}$, R. D. Kalke ${ }^{2}$, P. Richard ${ }^{1}$ \\ ${ }^{1}$ Centre de Recherche en Ecologie Marine et Aquaculture de L'Houmeau, UMR 10, CNRS-IFREMER, BP5, \\ Place du Séminaire, 17137 L'Houmeau, France \\ ${ }^{2}$ University of Texas at Austin, Marine Science Institute, 750 Channel View Drive, Port Aransas, Texas 78373-5015, USA
}

\begin{abstract}
The trophic dynamic links of migratory juvenile brown shrimp Penaeus aztecus were investigated along the South Texas coast from the Aransas Pass to Corpus Christi and Nueces Bay and to the nursery ground in the Nueces Delta. Shrimps and their potential food sources were measured for $\delta^{13} \mathrm{C}$ and $\delta^{15} \mathrm{~N}$ ratios between December 1995 and July 1996. During this period, shrimp length increased from 10 to $11 \mathrm{~mm}$, when the animals entered Corpus Christi Bay as larvae, to $80-90 \mathrm{~mm}$, when they returned to Mexico Gulf as sub-adults. Brown shrimp exhibited spatial and temporal $\delta^{13} \mathrm{C}$ variation (from -25.2 to $12.5 \%$ ), indicating a high diversity of food sources throughout their migration. From $\delta^{13} \mathrm{C}$ values, the main sources used as food sources by juvenile brown shrimp in the Rincon Bayou marsh were Spartina alterniflora and $S$. spartinae detritus and benthic diatoms. $\delta^{13} \mathrm{C}$ and $\delta^{15} \mathrm{~N}$ values showed that organic matter inputs carried by the river inflow can also contribute significantly to the feeding of migratory brown shrimp. In these marsh habitats, shrimp isotopic ratios changed rapidly, suggesting high tissue turnover rates. The study showed that coastal marshes after restoration through the introduction of freshwater inflow may provide feeding habitats favorable for growth and development of juvenile brown shrimp.
\end{abstract}

KEY WORDS: Penaeus aztecus $\cdot$ Food sources $\cdot$ Migration $\cdot$ Nursery area $\cdot \delta^{13} \mathrm{C}$ and $\delta^{15} \mathrm{~N}$

\section{INTRODUCTION}

Many marine species utilize salt marshes, coastal lagoons and estuaries during part of their life cycle (Day et al. 1989). The brown shrimp Penaeus aztecus Ives is widely distributed along the Texas coastline, where it is an important commercial fishery. Like most penaeids, the life history of brown shrimp is complex (Dall et al. 1990). In the Gulf of Mexico, after offshore spawning, post-larval brown shrimps are carried by the onshore water movement and enter bays and shallow estuarine waters, where they generally find pro-

\footnotetext{
-Present address: Station Biologique de Roscoff, Université Pierre \& Marie Curie Paris Vl, UPR 9042, Place GeorgesTeissier, BP 74, 29682 Roscoff cedex, France.

E-mail: riera@sb-roscoff.fr
}

ductive areas and are protected from storms and predators (Day et al. 1989, Fry 1981). Following growth of juvenile shrimp in nursery areas, there is a subsequent offshore migration of sub-adults to complete their life cycle. More precisely, throughout the Texas bay systems, most of the larval brown shrimp enter marine bays from late winter through early spring, spend about 3 to $4 \mathrm{mo}$ in estuarine nursery grounds, and return to the offshore Gulf of Mexico in early summer (Moffett 1970). However, the shrimp fishery is an exploited resource in the Gulf of Mexico (Parker et al. 1988). Restoration of coastal marshes, which act as nurseries, could contribute to increased brown shrimp populations because the marshes provide habitats for juveniles. Enhancing freshwater inflow may have at least 2 beneficial effects for restoring shrimp habitats: terrestrial inputs may be used as food sources (Hackney \& Haines 1980, Riera \& Richard 1996), and fresh- 
water inflow may increase the total primary production through nutrient inputs (Nixon et al. 1986).

The food sources utilized by juvenile brown shrimp during migration are more difficult to determine than those of adults, which live in deeper offshore environments that are generally phytoplankton-based systems (Fry \& Parker 1979). As juvenile penaeids migrate, they occupy different habitats, which correspond to different feeding grounds (Dall et al. 1990). Food availability can differ greatly within and between these habitats (Fry 1981), and different food sources may be used preferentially by shrimp. For example, stomach content analyses of small juvenile Penaeus semisculatus were composed of a large variety of prey including diatoms, meiofauna, insect larvae and seagrass (Heales et al. 1996). Moreover, Wassenberg \& Hill (1987) observed large intraspecific differences in the food ingested by $P$. esculentus collected from widely separated areas. Using immunological methods, it was found that the $P$. aztecus and $P$. setiferus have a diverse diet (Hunter \& Feller 1987).

Stable isotope analysis has been used successfully to determine original food sources of marine and estuarine invertebrates (Harrigan et al. 1989). Stable isotopes assess food sources assimilated over time (Fry \& Sherr 1984), so they are valuable for feeding studies when material in gut contents are difficult to identify due to digestion and trituration. Variation in $\delta^{13} \mathrm{C}$ values of the migratory brown shrimp along the South Texas coast has been investigated previously (Fry \& Parker 1979, Fry 1981). These studies have pointed out that seagrass meadows of shallow-water habitats were important feeding grounds for migratory juvenile brown shrimp. However, little is known about spatial and temporal variation of food sources encountered by brown shrimp throughout a complete migration between oceanic waters and upper estuarine reaches. As suggested by Fry (1981), habitats other than seagrass meadows may contribute significantly to the feeding of migrating shrimps. Therefore, it is important to know which feeding habitats contribute the most to the growth and development of the brown shrimp along the Texas coastline.

The aim of the present study was to identify the trophic dynamic links of migratory Penaeus aztecus with food sources in various habitats along the
South Texas coast. Shrimp migrations were followed from the Aransas Pass to Corpus Christi and Nueces Bay and to the ultimate nursery ground in the Nueces Delta. A primary objective was to determine if the primary production in a coastal marsh, which is currently being restored by the reintroduction of freshwater inflow, can support the feeding and growth of juvenile brown shrimps. Shrimp and potential food sources were determined by stable isotope analyses $\left(\delta^{13} \mathrm{C}\right.$ and $\left.\delta^{15} \mathrm{~N}\right)$

\section{MATERIAL AND METHODS}

Sampling area. The study was carried out in the Nueces Estuary (Fig. 1). The estuary consists of the Nueces River, the Rincon Bayou marsh and the Rincon Bayou mouth. The Nueces River empties into Nueces Bay, which is connected to Corpus Christi Bay, which is connected to the Gulf of Mexico by the Aransas Pass. Historically, the Nueces River fed into Rincon Bayou,

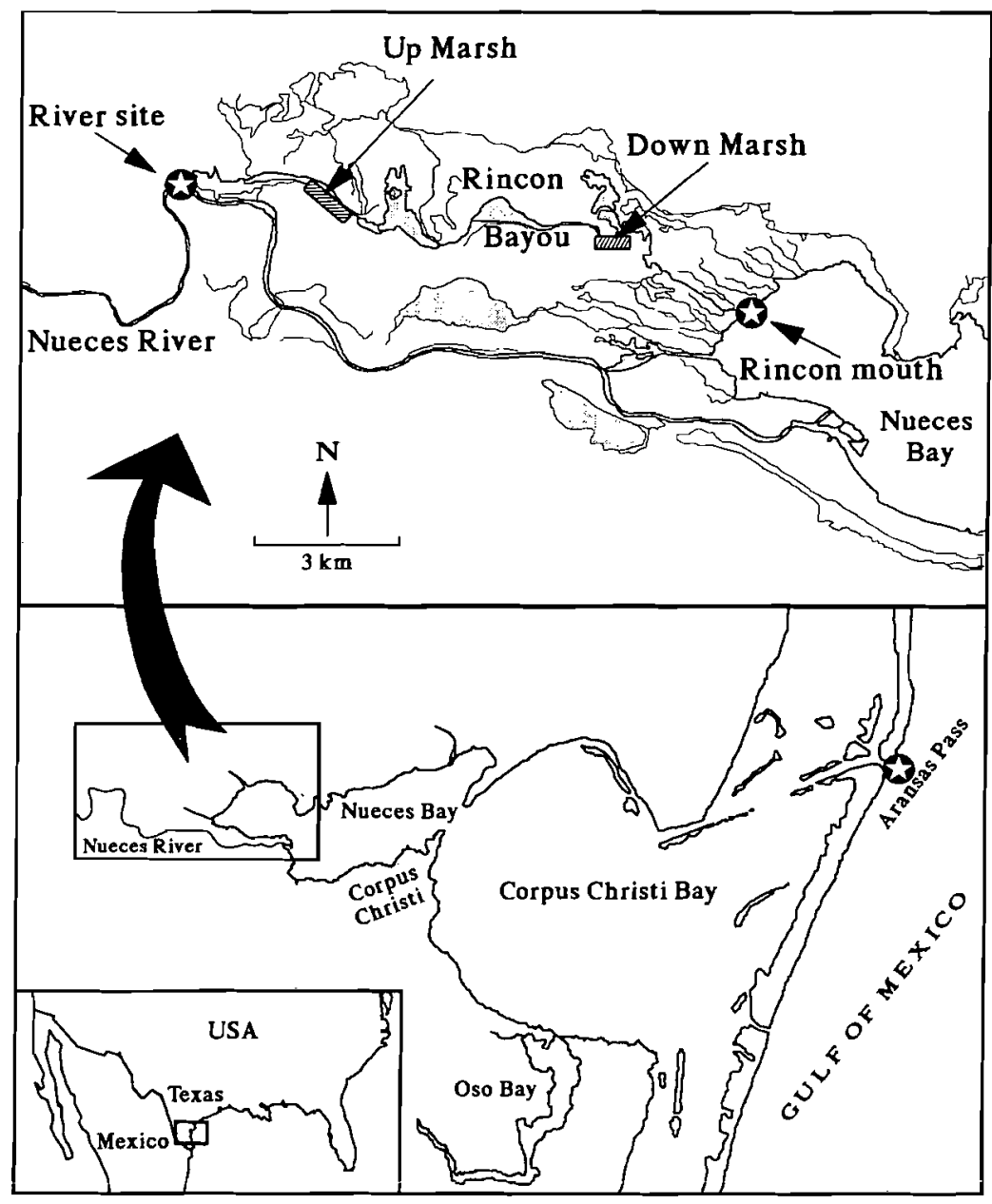

Fig. 1. Sampling areas in the Nueces Estuary along the South Texas coast, USA 
which is in the center of the Nueces Delta. A dam was created early in the 20th century to contain Nueces River water. Recently, the dam was lowered to allow flood events from Nueces River to flow into the Rincon Bayou to restore the Rincon Bayou marsh. Sampling locations into Rincon Bayou marsh (Fig. 1) were distributed from the freshwater entrance into Rincon Bayou marsh (River site) to the Rincon Bayou mouth (Rincon mouth). Sampling stations also included 'Up Marsh' and 'Down Marsh' within Rincon Bayou marsh, and 'Aransas Pass', which connected Corpus Christi Bay to the Gulf of Mexico. These sites have been considered because, as reported by Moffett (1970), they may lie on the migratory route of brown shrimps that enter Corpus Christi Bay through Aransas Pass.

Collection and preparation of samples. Sampling for organic matter sources and brown shrimp was carried out during from December 1995 to July 1996. Shrimp were collected by otter trawls or hand-thrown cast nets. They were sorted by hand and kept in seawater obtained from the sampling site so that guts can be purged prior to analysis. At the laboratory, shrimp were identified to the species levels using a magnifying glass and keys, measured (length) and were frozen $\left(-80^{\circ} \mathrm{C}\right)$. For stable isotope analyses shrimp were prepared according to Fry \& Parker (1979). White muscle tissue was dissected from the shrimp abdomen, acidified $(10 \% \mathrm{HCl})$ to remove any residual carbonates from cuticules, rinsed with distilled water, and dried in an oven at $60^{\circ} \mathrm{C}$. Then, to homogenize the sample the white muscle of each individual was ground to a fine powder with a mortar and pestle. Individuals were used as samples except when shrimp were too small to obtain sufficient tissue for accurate $\delta^{13} \mathrm{C}$ and $\delta^{15} \mathrm{~N}$ analyses. For larval shrimp, 6 or 8 individuals (10 to $11 \mathrm{~mm}$ size length) from the same sampling occasion were combined. Some of the brown shrimp collected and analysed for $\delta^{13} \mathrm{C}$ were also measured for $\delta^{15} \mathrm{~N}$. Zooplankton was collected with a $(176 \mu \mathrm{m})$ mesh net in Nueces Bay near Rincon mouth (Fig. 1). Samples of zooplankton were acidified $(10 \%$ $\mathrm{HCl})$ to remove any residual carbonates from cuticules, rinsed with distilled water, dried in an oven at $60^{\circ} \mathrm{C}$ and ground to a fine powder with a mortar and pestle to homogenize the sample.

Corixidae Corix sp. and mysids Mysidopsis almyra were sampled at Up Marsh on different occasions, between April 1995 and February 1996, by using the same procedure as for brown shrimp. Composite samples of corixidae ( 8 individuals) and mysids were prepared in the same way as for zooplankton and brown shrimp, respectively.

For sampling particulate organic matter (POM), 151 of water were collected, and then filtered on precombusted Whatman GF/F glass fiber filters under moder- ate vacuum within $5 \mathbf{h}$ after collection. Samples were acidified $(10 \% \mathrm{HCl})$ to remove carbonates, dried at $60^{\circ} \mathrm{C}$ and kept frozen $\left(-80^{\circ} \mathrm{C}\right)$ until analysis. For sedimented organic matter (SOM) analysis, sediment samples were taken in the Nueces River at River site and in the Rincon Bayou marsh at Up Marsh and Down Marsh by scraping the upper $1 \mathrm{~cm}$ of mud. At the laboratory, samples were homogenized, dried at $60^{\circ} \mathrm{C}$, ground using a mortar and pestle, and then acidified (10\% $\mathrm{HCl}$ ) to remove any inorganic carbon. These samples were not rinsed to prevent any loss of dissolved organics. They were dried overnight at $50^{\circ} \mathrm{C}$ under a slight vacuum to evaporate the acid. Once dried, the sediment was mixed with Milli-Q water, freeze-dried, ground again to a fine powder and kept frozen $\left(-80^{\circ} \mathrm{C}\right)$ until analysis.

At Rincon mouth, leaves and twigs of the 2 dominant marine phanerogames, Spartina alterniflora and Salicornia sp., were collected. For samples of terrestrial organic matter, leaves of the dominant vascular plants, namely Salix sp., Fraxinus sp. and the switchgrass Panicum virgatum, were collected along the Nueces River up to River site. Most samples within Rincon Bayou marsh were the Gulf cord grass Spartina spartinae, which dominates along the Rincon Bayou channel. These plant samples were cleaned of epibionts, and prepared similarly to shrimp muscle tissue. Blue green algal mats were collected in the Rincon Bayou channel and acidified $(10 \% \mathrm{HCl})$, rinsed with distilled water, freeze-dried, and frozen until analysis. Benthic diatoms were also sampled from muddy sediments near the Rincon Bayou channel, and separated using a procedure from Couch (1989) as modified by Riera \& Richard (1996). Briefly, the surficial sediments with dense microalgal mats were scraped and transported to the laboratory, where they were spread on flat trays to a depth of about $1 \mathrm{~cm}$. A nylon screen (63 $\mu \mathrm{m}$ mesh) was laid upon the sediment surface and covered with a 4 to $5 \mathrm{~mm}$ layer of combusted silica powder (60 to $210 \mu \mathrm{m}$ ). After $12 \mathrm{~h}$, the top $2 \mathrm{~mm}$ of the silica powder was gently scraped and then filtered on previously combusted glass fiber filters, acidified (10\% $\mathrm{HCl})$, rinsed with distilled water, freeze-dried, and frozen $\left(-80^{\circ} \mathrm{C}\right)$

Stable isotope analysis. Samples for isotope analyses were combusted at $900^{\circ} \mathrm{C}$ using $\mathrm{CuO}$ as an oxidant in evacuated quartz tubes (Stump \& Frazer 1973). Samples for isotope analyses were prepared as in Boutton (1991). Before the purification of $\mathrm{CO}_{2}, \mathrm{~N}_{2}$ was trapped on silica gel granules in a stopcock sample ampule and analyzed immediately after $\mathrm{CO}_{2}$ collection (Mariotti 1982). The carbon and nitrogen isotope ratios were measured using a Sigma 200 (CJS Sciences) double inlet, triple collector isotope ratio mass spectrometer. Data are expressed in the standard $\delta$ unit notation, 
where $\delta X=\left[\left(R_{\text {sample }} / R_{\text {reference }}\right)-1\right] \times 10^{3}$, with $R={ }^{13} \mathrm{C} /{ }^{12} \mathrm{C}$ for carbon and ${ }^{15} \mathrm{~N} /{ }^{14} \mathrm{~N}$ for nitrogen, and reported relative to the Pee Dee Belemnite standard for. carbon and to air $\mathrm{N}_{2}$ for nitrogen. The typical precision of the overall procedure (i.e., preparation plus analysis) was $\pm 0.1 \%$ for carbon and $\pm 0.2 \%$ o for nitrogen.

\section{RESULTS}

\section{$\delta^{13} \mathrm{C}$ and $\delta^{15} \mathrm{~N}$ of POM, SOM, sources and invertebrates}

$\delta^{13} \mathrm{C}$ and $\delta^{15} \mathrm{~N}$ of POM, SOM, plant sources and invertebrates are presented in Table 1. There was a gradient in carbon isotope values from the sea to the river. At Aransas Pass, POM $\delta^{13} \mathrm{C}$ values were between -24.8 and $-22.0 \%$ while at the Nueces River site, POM $\delta^{13} \mathrm{C}$ ranged from -28.8 to $-26.3 \%$. POM $\delta^{13} \mathrm{C}$ at Rincon Bayou mouth ranged from -27.2 to $-20.8 \%$. Within Rincon Bayou marsh, POM exhibited a large range for $\delta^{13} \mathrm{C}$, from -26.3 to $-17.4 \%$ at Down Marsh, and from -24.1 to $-17.1 \%$ at Up Marsh. Corresponding $\delta^{15} \mathrm{~N}$ values for POM ranged from 3 to $11 \%$ at Aransas Pass, from 8.8 to $10.8 \%$ at Nueces River and from 9.2 to $9.4 \%$ at Rincon Bayou mouth. Within Rincon Bayou marsh, POM $\delta^{15} \mathrm{~N}$ ranged from 2.6 to $9.3 \% . \delta^{13} \mathrm{C}$ for SOM (i.e., including benthic algae) ranged from -24.0 to $-22.2 \%$ at Nueces River and from -21.8 to $-20.2 \%$ in Rincon Bayou marsh. SOM $\delta^{15} \mathrm{~N}$ values were between 7.1 and $8.2 \%$ in Rincon Bayou marsh. At Rincon Bayou mouth, $\delta^{13} \mathrm{C}$ values ranged from -27.8 to $-26.3 \%$ for Salicornia sp. and from -16.2 to $-13.7 \%$ for Spartina alterniflora, typical of $\delta^{23} \mathrm{C}$ for $\mathrm{C} 3$ and $\mathrm{C} 4$ plants, respectively (Fry $\&$ Sherr 1984, Currin et al, 1995) and close to values previously observed for Spartina sp. and Salicornia sp. by Creach (1997). Within Rincon Bayou marsh, $\delta^{13} \mathrm{C}$ for Spartina spartinae ranged from $-16: 8$ to $-14.5 \%$. Benthic diatoms inhabiting muddy sediments near the Rincon Bayou channel had $\delta^{13} \mathrm{C}$ values from -18.5 to $-16.3 \%$. Blue green algae had $\delta^{13} \mathrm{C}$ from -15.7 to $-15.9 \%$ typical of ${ }^{13} \mathrm{C}$-enriched surficial blue-green algal mats from Texas (Calder \& Parker 1973). Blue green algae were the most ${ }^{15} \mathrm{~N}$-depleted primary producers with $\delta^{15} \mathrm{~N}$ from -0.7 to $1.7 \%$. $\delta^{13} \mathrm{C}$ values for leaves of the most common terrestrial vegetation along Nueces River, from -30.3 to $-27.6 \%$ for Fraxinus sp. and Salix sp.,
Table 1. $\delta^{13} \mathrm{C}$ and $\delta^{15} \mathrm{~N}$ (range values) of POM, SOM, the main organic matter sources and invertebrates in a South Texas estuary between Aransas Pass and Nueces River from December 1995 to July 1996. n: number of samples; -: not sampled

\begin{tabular}{|c|c|c|c|}
\hline Sampling site & Source & $\delta^{13} \mathrm{C}$ & $\delta^{15} \mathrm{~N}$ \\
\hline \multirow[t]{5}{*}{ Nueces River } & Riverine POM & $\begin{array}{c}-28.8 \text { to }-26.3 \\
(n=6)\end{array}$ & $\begin{array}{l}8.8 \text { to } 10.8 \\
(n=3)\end{array}$ \\
\hline & Riverine SOM & $\begin{array}{c}-24.0 \text { to }-22.2 \\
(\mathrm{n}=3)\end{array}$ & $\begin{array}{c}4.7 \\
(n=1)\end{array}$ \\
\hline & Fraxinus sp. & $\begin{array}{c}-29.1 \text { to }-27.6 \\
(\mathrm{n}=5)\end{array}$ & $\begin{array}{c}6.6 \\
(n=1)\end{array}$ \\
\hline & Salix sp. & $\begin{array}{c}-30.3 \text { to }-29.2 \\
(n=6)\end{array}$ & $\begin{array}{l}7.4 \text { to } 9.6 \\
(n=3)\end{array}$ \\
\hline & Panicum virgatum & $\begin{array}{c}-15.9 \text { to }-14.6 \\
(n=5)\end{array}$ & $\begin{array}{l}-1.6 \\
(n=1)\end{array}$ \\
\hline \multirow[t]{7}{*}{$\begin{array}{l}\text { Rincon Bayou } \\
\text { marsh }\end{array}$} & Marsh POM & $\begin{array}{c}-26.3 \text { to }-17.1 \\
(\mathrm{n}=20)\end{array}$ & $\begin{array}{l}2.6 \text { to } 9.3 \\
(\mathrm{n}=12)\end{array}$ \\
\hline & Marsh SOM & $\begin{array}{c}-21.8 \text { to }-20.2 \\
(n=7)\end{array}$ & $\begin{array}{l}7.1 \text { to } 8.2 \\
(\mathrm{n}=2)\end{array}$ \\
\hline & Spartina spartinae & $\begin{array}{c}-16.8 \text { to }-14.5 \\
(n=3)\end{array}$ & $\begin{array}{c}7.6 \\
(n=1)\end{array}$ \\
\hline & Benthic diatoms & $\begin{array}{c}-18.5 \text { to }-16.3 \\
(\mathrm{n}=5)\end{array}$ & $\begin{array}{l}3.2 \text { to } 6.0 \\
(n=2)\end{array}$ \\
\hline & Blue green algae & $\begin{array}{c}-15.8 \text { to }-15.7 \\
(n=2)\end{array}$ & $\begin{array}{c}-0.7 \text { to } 1.7 \\
(n=2)\end{array}$ \\
\hline & Corix sp. & $\begin{array}{c}-20.8 \text { to }-16.2 \\
(n=4)\end{array}$ & $\begin{array}{l}-0.2 \\
(n=1)\end{array}$ \\
\hline & Mysidopsis almyra & $\begin{array}{c}-21.6 \text { to }-20.5 \\
(n=3)\end{array}$ & $\begin{array}{c}10.5 \text { to } 10.8 \\
(\mathrm{n}=2)\end{array}$ \\
\hline \multirow[t]{6}{*}{$\begin{array}{l}\text { Rincon Bayou } \\
\text { mouth }\end{array}$} & POM & $\begin{array}{l}-27.2 \text { to }-20.8 \\
(n=4)\end{array}$ & $\begin{array}{l}9.2 \text { to } 9.4 \\
(\mathrm{n}=2)\end{array}$ \\
\hline & $\begin{array}{l}\text { Spartina alterniflora } \\
\text { (fresh leaves) }\end{array}$ & $\begin{array}{c}-16.2 \text { to }-15.8 \\
(\mathrm{n}=2)\end{array}$ & - \\
\hline & $\begin{array}{l}\text { Spartina alterniflora } \\
\text { (old leaves and twigs) }\end{array}$ & $\begin{array}{c}-15.2 \text { to }-13.7 \\
(n=6)\end{array}$ & $\begin{array}{c}2.6 \\
(\mathrm{n}=1)\end{array}$ \\
\hline & $\begin{array}{l}\text { Salicornia sp. } \\
\text { (fresh leaves) }\end{array}$ & $\begin{array}{c}-27.7 \text { to }-26.7 \\
(n=4)\end{array}$ & - \\
\hline & $\begin{array}{l}\text { Salicornia sp. } \\
\text { (old leaves and twigs) }\end{array}$ & $\begin{array}{c}-27.8 \text { to }-26.3 \\
(n=5)\end{array}$ & $\begin{array}{l}3.3 \text { to } 7.3 \\
(n=3)\end{array}$ \\
\hline & Zooplankton & $\begin{array}{c}-26.3 \text { to }-25.6 \\
(n=3)\end{array}$ & $\begin{array}{c}11.7 \\
(n=1)\end{array}$ \\
\hline Aransas Pass & Ocean POM & $\begin{array}{c}-24.8 \text { to }-22.0 \\
\quad(n=8)\end{array}$ & $\begin{array}{c}3.0 \text { to } 11.1 \\
(\mathrm{n}=5)\end{array}$ \\
\hline
\end{tabular}

were typical of terrestrial C3 plants (Degens 1969). $\delta^{13} \mathrm{C}$ of Panicum virgatum ranged from -15.9 to $-14.6 \%$, indicating a $\mathrm{C} 4$ photosynthetic pathway (Fry \& Sherr 1984). At Rincon Bayou mouth zooplankton was ${ }^{13} \mathrm{C}$-depleted (from -26.3 to $-25.6 \%$ ) and ${ }^{15} \mathrm{~N}$-enriched $(11.7 \%$ ). Within Rincon Bayou marsh Corix sp. and Mysidopsis almyra showed $\delta^{13} \mathrm{C}$ from -20.8 to $-16.2 \%$ and from -21.6 to $-20.5 \%$, respectively. Corresponding $\delta^{15} \mathrm{~N}$ values were $-0.2 \%$ for Corix sp. and from 10.5 to $10.8 \%$ for Mysidopsis almyra. 
Fig. 2. Length of individual brown shrimp Penaeus aztecus $(\mathrm{n}=111)$ at the different sampling habitats between Aransas Pass and Nueces River. Sampling dates: $d / m o$ (1996)

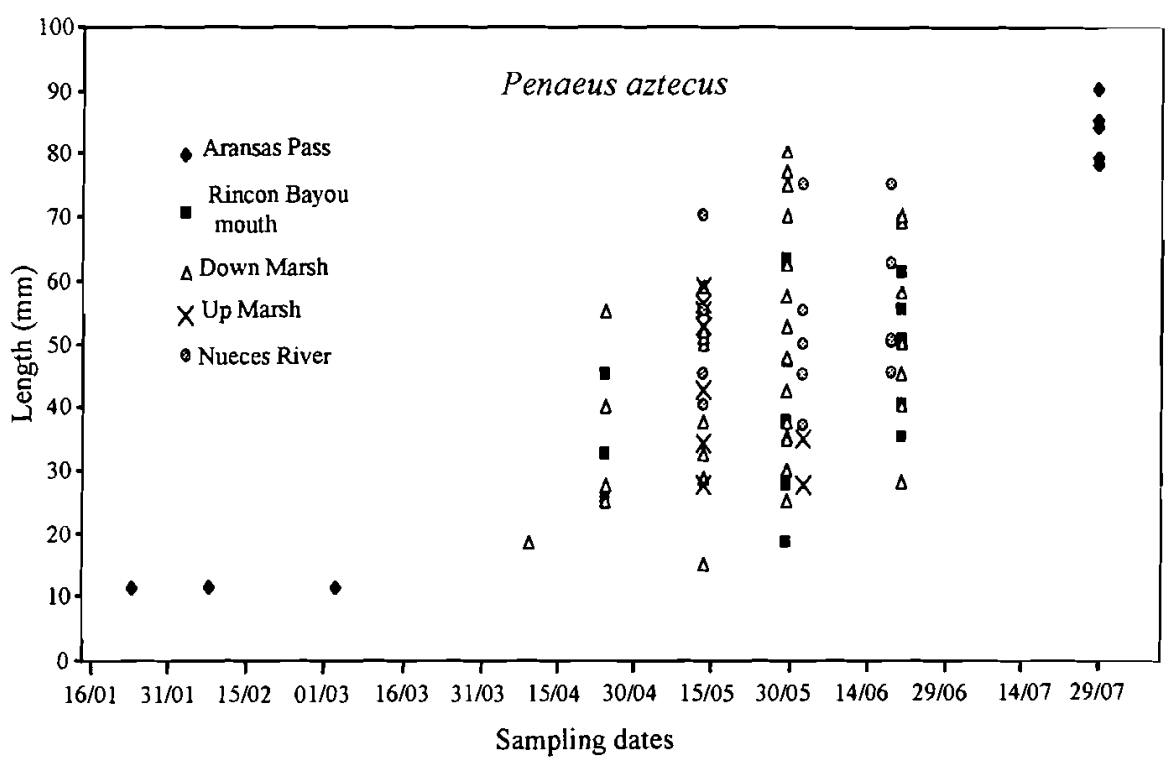

their $\delta^{13} \mathrm{C}$ ranged from -25.2 to $-20.4 \%$. $\delta^{13} \mathrm{C}$ for Penaeus aztecus were significantly different among the sampling sites (Kruskal-Wallis test $=35.3, \mathrm{df}=4$, $\mathrm{p}<0.001$ ). At Aransas Pass, $\delta^{15} \mathrm{~N}$ values were between 5.5 and $7.7 \%$ for larval shrimp and between 3.3 and $9.7 \%$ for sub-adults. $\delta^{15} \mathrm{~N}$ ranged from 4.5 to $13.1 \%$ at Rincon Bayou mouth, from 1.0 to $9.9 \%$ at Down Marsh and from 1.2 to $5.1 \%$ at Up Marsh. At the Nueces River site, $\delta^{15} \mathrm{~N}$ values ranged between 6.6 and $13.9 \%$. $\delta^{15} \mathrm{~N}$ values were also significantly different among the sampling sites (Kruskal-Wallis test $=36.8$, df $=4$, $\mathrm{p}<0.001$ ).

\section{DISCUSSION}

\section{$\delta^{13} \mathrm{C}$ variations of Penaeus aztecus throughout the migration}

Spatial and temporal $\delta^{13} \mathrm{C}$ of migrating brown shrimp exhibited variation throughout migration (Fig. 3) confirming the migratory pattern of juvenile brown shrimp in Texas bays previously observed (Moffet 1970, Fry 1981). The range of $\delta^{13} \mathrm{C}$ values for Peneaus aztecus (from -25.2 to $-12.5 \%$ ) is similar to the range of $\delta^{13} \mathrm{C}$ observed for the main sources of organic matter (from -30.3 to $-13.7 \%$ o). This observation is consistent with the hypothesis that a high diversity of food sources is used by brown shrimp throughout the migration. However, during each sampling date from January 25 to July 29 (Table 2, Fig. 3), there was littie variation in shrimp $\delta^{13} \mathrm{C}$ values ( $\mathrm{SD}<2 \%$ ), indicating that the shrimps had a similar diet at specific sites and times (de Niro \& Epstein 1978). Wide ranges of $\delta^{13} \mathrm{C}$ for invertebrates have been previously observed along salinity 


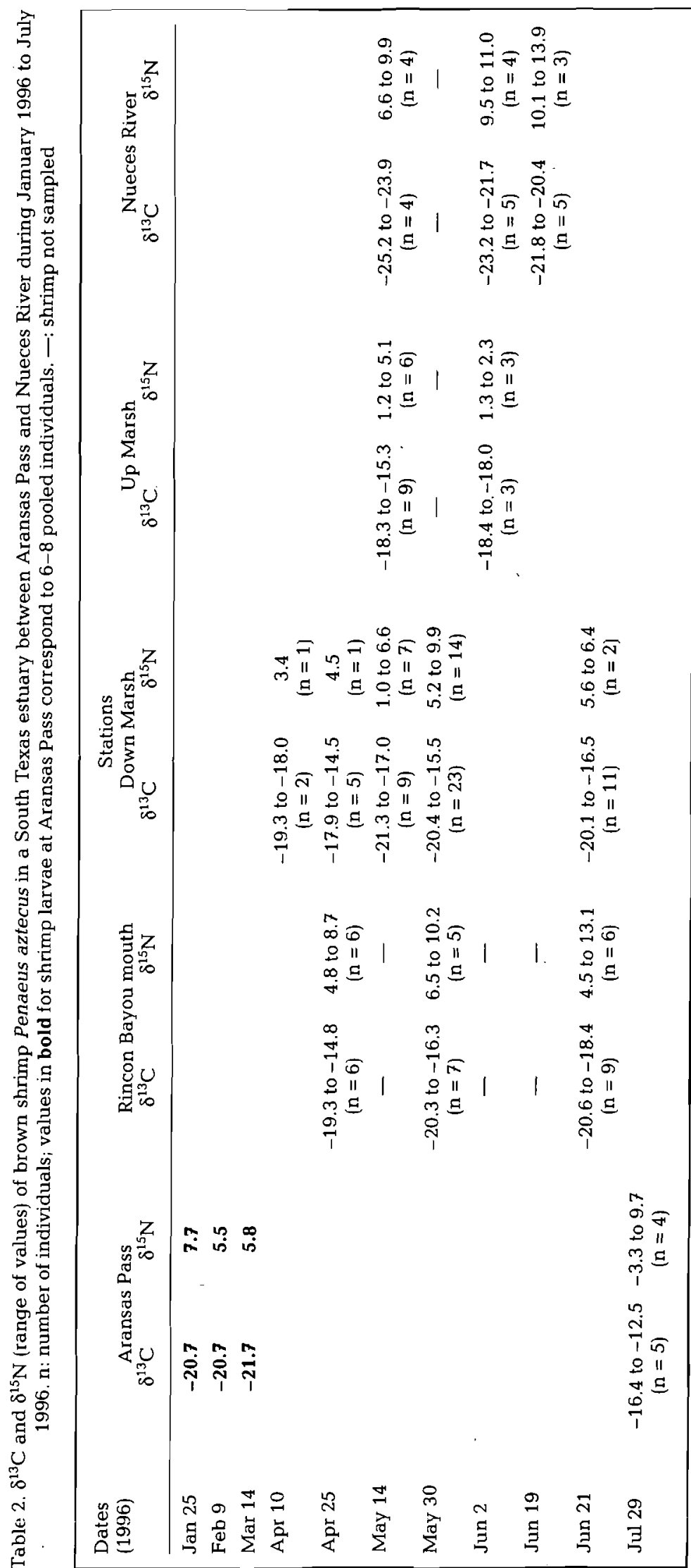

gradients (Incze et al. 1982, Hughes \& Sherr 1983). The oyster Crassostrea gigas exhibited significantly different $\delta^{13} \mathrm{C}$ variations between sites along an estuarine gradient, reflecting the preferential utilization of different food sources, namely, terrestrial detritus, benthic diatoms and marine phytoplankton (Riera \& Richard 1996). The present study suggests that individual $\delta^{13} \mathrm{C}$ variation of a migrating species (Penaeus aztecus) along an estuarine gradient can be as large as inter-individual $\delta^{13} \mathrm{C}$ variation of a sedentary species (C. gigas).

\section{Contribution of salt marsh sources to brown shrimp diet}

Salt marsh habitats appear to be important food sources for young brown shrimp. When entering Corpus Christi Bay through Aransas Pass, brown shrimp larvae had typically $\delta^{13} \mathrm{C}$ values $(-21.7$ to $-20.7 \%$ ) characteristic of animals feeding primarily on an oceanic planktonic food source (Fry \& Parker 1979, Incze et al. 1982). However, as they entered the mouth of Rincon Bayou through the Spartina alterniflora and Salicornia sp. marsh, brown shrimp became more ${ }^{13} \mathrm{C}$-enriched (-19.4 to $-16.8 \%$ ), indicating a significant contribution of a ${ }^{13} \mathrm{C}$ enriched source to shrimp diet. At Rincon mouth, suspended POM, Salicornia sp. and zooplankton were too ${ }^{13} \mathrm{C}$-depleted $(-27.3$ to $-24.2 \%$ ) to explain the enrichment in ${ }^{13} \mathrm{C}$ of migratory brown shrimp (Table 1, Fig. 3). Moreover, assuming phytoplankton is the main food source for zooplankton, and that the trophic $\delta^{13} \mathrm{C}$ enrichment is about $1 \%$ per trophic level (de Niro \& Epstein 1978), phytoplankton $\delta^{13} \mathrm{C}$ should be about $-27 \%$, which is too negative to be a major contribution to brown shrimp diet. The ${ }^{13} \mathrm{C}$-enrichment of brown shrimp at the mouth of Rincon Bayou can be explained by a significant contribution of carbon derived from $S$. alterniflora detritus ( -16 to $-14.5 \%$ o). Consistent with these results, plant detritus derived from Zostera sp., Phragmites sp. or Spartina sp. were found in gut contents of post-larval penaeids, indicating that marsh detritus may be a food source for these shrimps when they occupy that habitat (see Dall et al. 1990). Likewise, mangrove detritus has been shown to con- 

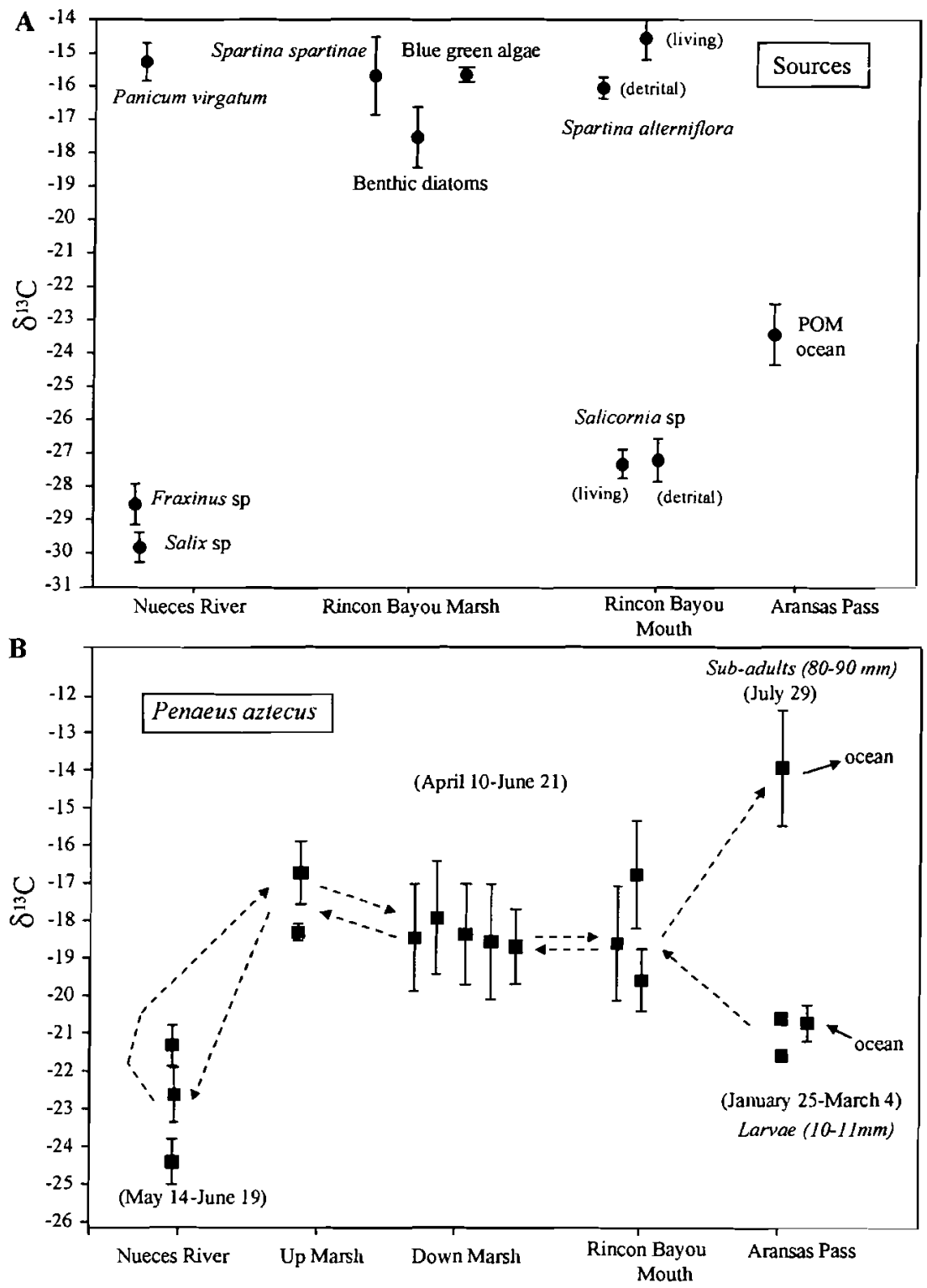

Fig. 3. (A) Carbon isotopic ratios (mean $\pm \mathrm{SD}$ ) of the main organic matter sources in the Nueces Estuary. (B) Variations (mean \pm SD) of carbon isotopic ratios of juvenile brown shrimps Penaeus aztecus on the different sampling occasions throughout the migration between Aransas Pass and Nueces River. Periods of collection of $P$. aztecus in the different habitats are indicated in parentheses. - - - : schematisation of the migration route

tribute to the diet of juvenile Penaeus merguiensis inhabiting tidal creeks in Peninsular Malaysia (Newell et al. 1995). In contrast, from feeding experiments Gleason \& Wellington (1988) reported that $S$. alterniflora detritus and its epiphytes contributed only a small part of $P$. aztecus assimilated carbon. Finally, Dall et al. (1990) concluded that plant detritus itself is not a major food source for prawns.

The results of the present study indicated that detritus derived from Spartina alterniflora can be an impor- tant carbon source to juvenile brown shrimp. However, Penaeus aztecus may assimilate carbon that is ultimately derived from Spartina spp. via several routes other than direct feeding on plants detritus. It is possible that $P$. aztecus may obtain part of its carbon derived from $S$, alterniflora detritus through microbial mediation. For example, in ${ }^{14} \mathrm{C}$ labelling experiments, the grass shrimp Palaemonetes pugio could assimilate carbon from detrital $S$. alterniflora with $38.4 \%$ efficiency via bacterial mediation between non-living organic detritus and shrimp (Crosby 1985). In fact, bacteria associated with debris of refractory plant material can facilitate the carbon transfer from plant sources to bivalves (Langdon \& Newell 1990, Crosby et al. 1990).

As brown shrimp occupied the down and up marsh, they remained ${ }^{13} \mathrm{C}$-enriched $(-19$ to $-17 \%)$, indicating a persistence in their utilisation of a relatively heavy ${ }^{13} \mathrm{C}$ source (Fig. 3). Although there is no Spartina alterniflora within the Rincon Bayou marsh, these $\delta^{13} \mathrm{C}$ values may be explained by utilization of benthic diatoms, blue green algae and/or detritus derived from $S$. spartinae as the carbon source (Fig. 3). However, the respective contributions of these ${ }^{13} \mathrm{C}$-enriched sources to brown shrimp feeding cannot be established from $\delta^{13} \mathrm{C}$ values alone. It is known that benthic microalgae from mudflats represent one of the dominant food source for juvenile penaeids within tidal creeks in Peninsular Malaysia (Newell et al. 1995). Also, a positive growth rate of postlarval brown shrimp can be supported over $16 \mathrm{~d}$ by feeding only on the planktonic diatom Skeletonema costatum (Gleason \& Zimmerman 1984). Although living microalgae can be more readily used than detritus of vascular plants, as shown for marine bivalves (Bayne et al. 1987, Crosby et al. 1989), a significant contribution of detritus derived from Spartina spartinae to shrimp diet may also account for the observed carbon isotope values. These results are in accordance with recent isotopic data of Deegan \& Garritt (1997) showing a preferential utilisation of local sources organic matter in coastal marsh areas by invertebrates. 


\section{Contribution of riverine inputs to brown shrimp diet}

$\delta^{13} \mathrm{C}$ values also changed as shrimp moved near and into areas that are subject to freshwater inundation. In May and June 1996, juvenile brown shrimp were collected at the Nueces River site up to Rincon Bayou marsh (Fig. 1). Other shrimp, e.g. Penaeus merguiensis (Staples 1980) and P. setiferus (Dall et al. 1990), have also been observed in lower salinity environments far upstream from the river mouth. As juvenile brown shrimp occupied Nueces River, their $\delta^{13} \mathrm{C}$ became significantly more negative $(-24$ to $-21 \%)$ compared with $\delta^{13} \mathrm{C}$ measured within Rincon Bayou marsh (Fig. 3). This depletion in ${ }^{13} \mathrm{C}$ indicates that a significant part of brown shrimp carbon at Nueces River is derived from terrestrial detritus and/or riverine phytoplankton carried by freshwater inflow, because Rincon Bayou marsh lacks a ${ }^{13} \mathrm{C}$-depleted source (Fig. 3). Unfortunately, $\delta^{13} \mathrm{C}$ for riverine phytoplankton could not be estimated in the present study. However, previous results showed phytoplankton $\delta^{13} \mathrm{C}$ values of -44 to $-47 \%$ in rivers (Rau 1978) and of $-40 \%$ (Hedges et al. 1986) in a lake. Similarly, $\delta^{13} \mathrm{C}$ of freshwater phytoplankton in the Charente River (France) ranged between -41.8 and $-31.2 \%$ (Riera \& Richard 1996). Considering this higher depletion in ${ }^{13} \mathrm{C}$ for freshwater phytoplankton compared with terrestrial C3 plants, a primary contribution of riverine phytoplankton to the diet of brown shrimp is unlikely, but cannot be excluded.

In fact, because the metabolic ${ }^{13} \mathrm{C}$-enrichment during assimilation is close to $1 \%$ (De Niro \& Epstein 1978, Rau et al. 1983), shrimp $\delta^{13} \mathrm{C}$ values at Nueces River are consistent with a significant utilisation of terrestrial C3 plants (-29 to $-28 \%)$ as food source. Moreover, the similarity of $\delta^{13} \mathrm{C}$ values of terrestrial C3 plants (Salix sp., Fraxinus sp.) and POM in the Nueces River indicates that detritus from $\mathrm{C} 3$ plants contribute predominantly to river POM. Therefore, the results of this study can explain the depletion in ${ }^{13} \mathrm{C}$ for brown shrimp observed in lower salinity bays that are flushed by freshwater inflow or are most influenced by river inputs along the South Texas coast (Fry 1981). This result is consistent with the hypothesis that terrestrial organic inputs could be incorporated into estuarine food webs (Hackney \& Haines 1980, Incze et al. 1982). In fact, previous results have shown the significant contribution of terrestrial detritus derived from $\mathrm{C} 3$ plants to the diet of oysters (Crassostrea gigas) in the upper reaches of the Charente Estuary (Riera \& Richard 1996), and in the middle estuarine reaches as a high river discharge period occurred (Riera \& Richard 1997). In addition, from $\delta^{13} \mathrm{C}$ analyses, Stephenson \& Lyon (1982) reported that the bivalve Chione stutchburyi inhabiting the Avon-Heathcote Estuary (New Zealand) could utilise carbon of terrestrial origin depending upon its position in the estuary and local hydrology. Freshwater inputs can be an important source of nutrition for juvenile brown shrimp in habitats lacking salt marsh plants and benthic diatoms. Therefore, during periods of high river discharge, riverine inputs may support a substantial part of the food webs in South Texas bays and elsewhere as well.

\section{Offshore migration of sub-adult Penaeus aztecus}

Sub-adult Penaeus aztecus that are migrating offshore have different diets than the sub-adults found in marshes. An enrichment in ${ }^{13} \mathrm{C}$ for $P$. aztecus $(-13.8 \pm$ $1.5 \%$ ) was observed at Aransas Pass at the end of July 1996 (Fig. 3). Brown shrimp in Aransas Pass were likely returning towards the nearshore Gulf of Mexico because they were sub-adult size and offshore migration occurs in summer in Texas bays (Moffet 1970). Similar $\delta^{13} \mathrm{C}$ values, between -12.6 and $-14.6 \%$, were also observed by Fry \& Parker (1979) for brown shrimp collected offshore in the Gulf of Mexico, but more negative $\delta^{13} \mathrm{C}$ were observed for other shrimps $(P$. setiferus) from the same area. This enrichment in ${ }^{13} \mathrm{C}$ in shrimp tissues is not likely to be a result of a metabolic effect as shrimp grow due to a variation of carbon fractionation. In fact, the inter-individual $\delta^{13} \mathrm{C}$ variability among animals having a similar food source does not usually exeed $2 \%$ for fishes and invertebrates, these differences being attributed to size, age or sex (Fry \& Parker 1979, Hughes \& Sherr 1983). The $8 \%$ mean enrichment in ${ }^{13} \mathrm{C}$ in shrimp tissues (Fig. 3) between the marsh and pass locations in spring and summer may have other interpretations.

At Aransas Pass, phytoplankton was likely to be the main organic matter source for brown shrimps because there are no seagrass meadows. However, considering the $\delta^{13} \mathrm{C}$ of $-22.7 \%$ for marine phytoplankton in the Northern Gulf of Mexico given by Thayer et al. (1983), the enrichment in ${ }^{13} \mathrm{C}$ due to metabolic fractionation between phytoplankton and brown shrimps would be much more than $1 \%$. Most likely, less negative $\delta^{13} \mathrm{C}$ for brown shrimp, as they enter the offshore area, may be explained by a progressive enrichment in ${ }^{13} \mathrm{C}$ as shrimps returned from Nueces River environments towards offshore waters (Fig. 3), as suggested by Fry \& Parker (1979). In fact, the shrimps collected in late July, at the end of the migration, exhibited $\delta^{13} \mathrm{C}$ typical of the feeding habitats recently encountered where they used ${ }^{13} \mathrm{C}$-enriched food sources, e.g., marsh grass or seagrasses. Particularly, within Corpus Christi and Redfish Bays, seagrasses have the highest $\delta^{13} \mathrm{C}$ values $(-3$ to $-13 \%)$ in the ecosystem as reported by Fry \& Parker (1979). High $\delta^{13} \mathrm{C}$ of $-10 \%$ were also observed 
recently for seagrasses of Laguna Madre in South Texas (Street et al. 1997). Additionally, macroalgae is known to occur in bay bottoms and along the jetties at Aransas Pass, but we have not sampled this source. As they return towards marine waters through Rincon Bayou mouth shrimp may also increase their feeding on Spartina spp. detritus directly or through predation on detritivores. Therefore, as sub-adult brown shrimp feed offshore, their $\delta^{13} \mathrm{C}$ should progressively converge on the $\delta^{13} \mathrm{C}$ value characteristic of offshore environment, close to $-18 \%$ (Fry 1981).

\section{Temporal $\delta^{13} \mathrm{C}$ variation: importance for tissue turnover}

Tissue turnover rates are important to know to interpret temporal $\delta^{13} \mathrm{C}$ variation. There was about a $3.5 \%$ decrease in $\delta^{13} \mathrm{C}$ values from the Up Marsh to the Nueces River site (Fig. 3), indicating a high tissue turnover rate for brown shrimp as they migrate. This isotopic $\delta^{13} \mathrm{C}$ variation occurred over a distance of less than $5 \mathrm{~km}$ and within a period of $9 \mathrm{wk}$. From one feeding habitat to another the 'old carbon' of shrimp tissue is progressively diluted due to (1) growth of new tissue using 'new carbon' and (2) metabolic loss due to tissue turnover (Anderson et al. 1987). Therefore, after a variation in food, shrimp $\delta^{13} \mathrm{C}$ will change isotopically as rapidly as tissue turnover rate will allow (Fry 1982). In the present study, the $\delta^{13} \mathrm{C}$ decrease of migratory brown shrimp was consistent with a high tissue turnover rate, which support the hypothesis of a high growth rate in the nursery habitat. This suggestion is consistent with previous results based on experimental observations showing that postlarval shrimp can increase in weight by a factor of 4 within a week or less at $25^{\circ} \mathrm{C}$ (Zein-Eldin \& Aldrich 1965 ). A $14 \%$ variation for $\delta^{13} \mathrm{C}$ of postlarval brown shrimp has been observed after a 3.9-fold increase in weight after a change in food source, indicating a high tissue turnover rate (Fry \& Arnold 1982). From feeding experiments Gleason (1986) showed that the half-life of the initial tissue carbon of Penaeus aztecus fed with plant and animal diets was reached before the first doubling of weight. Finally, juvenile shrimp (initially $\delta^{13} \mathrm{C}:-18.6 \%$ ) in an experimental feeding pond with feed at $\delta^{13} \mathrm{C}:-22.9 \%$ for $8 \mathrm{wk}$ attained an equilibrium $\delta^{13} \mathrm{C}$ at $-21.3 \%$ after $3 \mathrm{wk}$ and an increase in weight of $300 \%$ (Parker et al. 1988). High tissue turnover rate for young shrimp can be related with behaviour and feeding activity. In fact, small juveniles of $P$. semisculatus were active and fed both day and night and are thought to feed continuously and to digest most of their food within only $1 \mathrm{~h}$ (Heales et al. 1996). It is likely that the variation in carbon isotope values of brown shrimp in the Rincon
Bayou Marsh are a result of changed food sources and rapid growth in this nursery habitat.

\section{Food sources determination from $\delta^{15} \mathrm{~N}$ values}

Although only part of the shrimp collected were measured for $\delta^{15} \mathrm{~N}$, a dual isotope approach is useful for identifying food sources. In both, Up and Down Rincon Bayou marshes, $\delta^{15} \mathrm{~N}$ for brown shrimp showed a high variability both between sampling periods and between individuals (Table 2). This is consistent with a higher range in $\delta^{15} \mathrm{~N}$ values for sources in this habitat (i.e., from -0.7 to $7.6 \%$ ) and suggests a high diversity of nitrogen sources for shrimps (i.e., Spartina spartinea, benthic diatoms, blue green algae). Lower $\delta^{15} \mathrm{~N}$ values that were observed for some shrimps in Rincon Bayou marsh could be explained by a depletion in ${ }^{15} \mathrm{~N}$ during nitrogen assimilation (Macko et al. 1982). In fact, these authors observed a mean $\delta^{15} \mathrm{~N}$ fractionation of $-0.3 \%$ for the amphipod Amphithoe valida fed with fresh and detrital algae. However, this hypothesis is unlikely for Penaeus species because feeding experiments demonstrated a trophic enrichment in ${ }^{15} \mathrm{~N}$ of $2.4 \%$ for $P$. vannamei (Parker et al. 1988). These lower $\delta^{15} \mathrm{~N}$ values for brown shrimp may partly result from a preferential assimilation of specific chemical components of plant tissues (Mako et al. 1982) and/or by the utilization of ${ }^{15} \mathrm{~N}$-depleted blue green algae (Table 1). Therefore, in the present study, $\delta^{15} \mathrm{~N}$ was not as valuable as $\delta^{13} \mathrm{C}$ to characterize food sources of brown shrimp. This result is consistent with the suggestion of Fry \& Sherr (1984) that $\delta^{15} \mathrm{~N}$ is not as discriminating as $\delta^{13} \mathrm{C}$ for food source determination in coastal ecosystems. However, at the Nueces River mean values of $\delta^{15} \mathrm{~N}$ for shrimp (i.e., 8.2, 10.1 and $11.7 \%$ ) are consistent with a significant utilization of the terrestrial C3 plants Fraxinus sp. (i.e., 6.6\%) and/or Salix sp. $(8.3 \pm$ $1.1 \%$ ) when taking into account the mean trophic enrichment for $\delta^{15} \mathrm{~N}$ (i.e., $3.5 \%$ given by Minagawa \& Wada 1984). In this riverine habitat, where terrestrially derived organic matter dominated, $\delta^{15} \mathrm{~N}$ values confirmed $\delta^{13} \mathrm{C}$ results.

\section{Importance of trophic mediation through predation}

Predation on animals can also be important for brown shrimp. Like many Penaeus species, P. aztecus can feed on different prey taxa including oligochaetes, polychaetes, crustaceans, mysids, mollusks and meiofauna (Hunter \& Feller 1987, Dall et al. 1990). In fact, the utilization of detritus derived from terrestrial and marsh vascular plants could occur indirectly through infaunal prey or through bacterial 
mediation (Gleason \& Zimmerman 1984). For example, juvenile $P$. merguiensis may use mangrove leaf detritus as a food source indirectly through predation on small detritivorous invertebrates (Newell et al. 1995). Detritus from Spartina alterniflora salt marshes may be predominant in the diet of meiofauna when an accumulation of detrital Spartina spp. is associated with the development of an important microbial biomass (Couch 1989). Then, meiofauna may also have a role in the trophic mediation between plant detritus and brown shrimp in these habitats. Likewise, benthic diatoms can be an indirect food source for juvenile shrimp through direct grazing or through intermediate infaunal prey (Stoner \& Zimmerman 1988). In the present study, Corixidae (Corix sp.) and mysids (Leptomis sp. and Mysidopsis almyra), which were collected frequently at the Nueces River and the Rincon Bayou marsh, could be part of the diet of $P$. aztecus. $\delta^{13} \mathrm{C}$ values (mean: $-17.9 \%$ ) and $\delta^{15} \mathrm{~N}(-0.2 \%)$ of Corix sp. may explain partly the enrichment in ${ }^{13} \mathrm{C}$ and the depletion in ${ }^{15} \mathrm{~N}$ observed for individuals of $P$. aztecus in Rincon Bayou marsh (Table 2). In contrast, isotopic values measured for both for zooplankton near Rincon Bayou mouth and M. almyra in Rincon Bayou marsh were too ${ }^{13} \mathrm{C}$-depleted and ${ }^{15} \mathrm{~N}$-depleted to contribute significantly to the feeding of brown shrimp in these 2 habitats.

\section{Variation in trophic level of brown shrimp}

Brown shrimp may vary their food sources and feed at different trophic levels during their migratory life cycle. Variations in brown shrimp feeding can be directly related with habitats. However, the habitat variations may be associated with a variation in the trophic level of shrimp. Variations in the diet of Penaeus sp. with size and age were partly attributed to the variation from a herbivorous to a carnivorous feeding mode as shrimp grow (Chong \& Sasekumar 1981). Therefore, shrimp $\delta^{15} \mathrm{~N}$ should become more positive as size increases. This effect should be more obvious in shrimp tissue with $\delta^{15} \mathrm{~N}$ than $\delta^{13} \mathrm{C}$ values, due to a higher $\delta^{15} \mathrm{~N}$ fractionation during assimilation. The relationship between $\delta^{15} \mathrm{~N}$ and shrimp length varies in each feeding habitat occupied by migratory brown shrimp, because nitrogen isotopic values at the base of the food chain can vary among the different habitats (Fig. 4). At Aransas Pass, this effect should have been especially clear, because brown shrimp size-range was largest there. However, there was no significant Pearson correlation between $\delta^{15} \mathrm{~N}$ and shrimp size at Aransas Pass $(r=-0.22, p>0.5)$, at Rincon Bayou mouth $(\mathrm{r}=0.12, \mathrm{p}>0.5)$, at Rincon Bayou marsh $(\mathrm{r}=$ $0.18, p>0.1)$ and at Nueces River $(r=0.35, p>0.1)$. These results indicate that differences in food sources
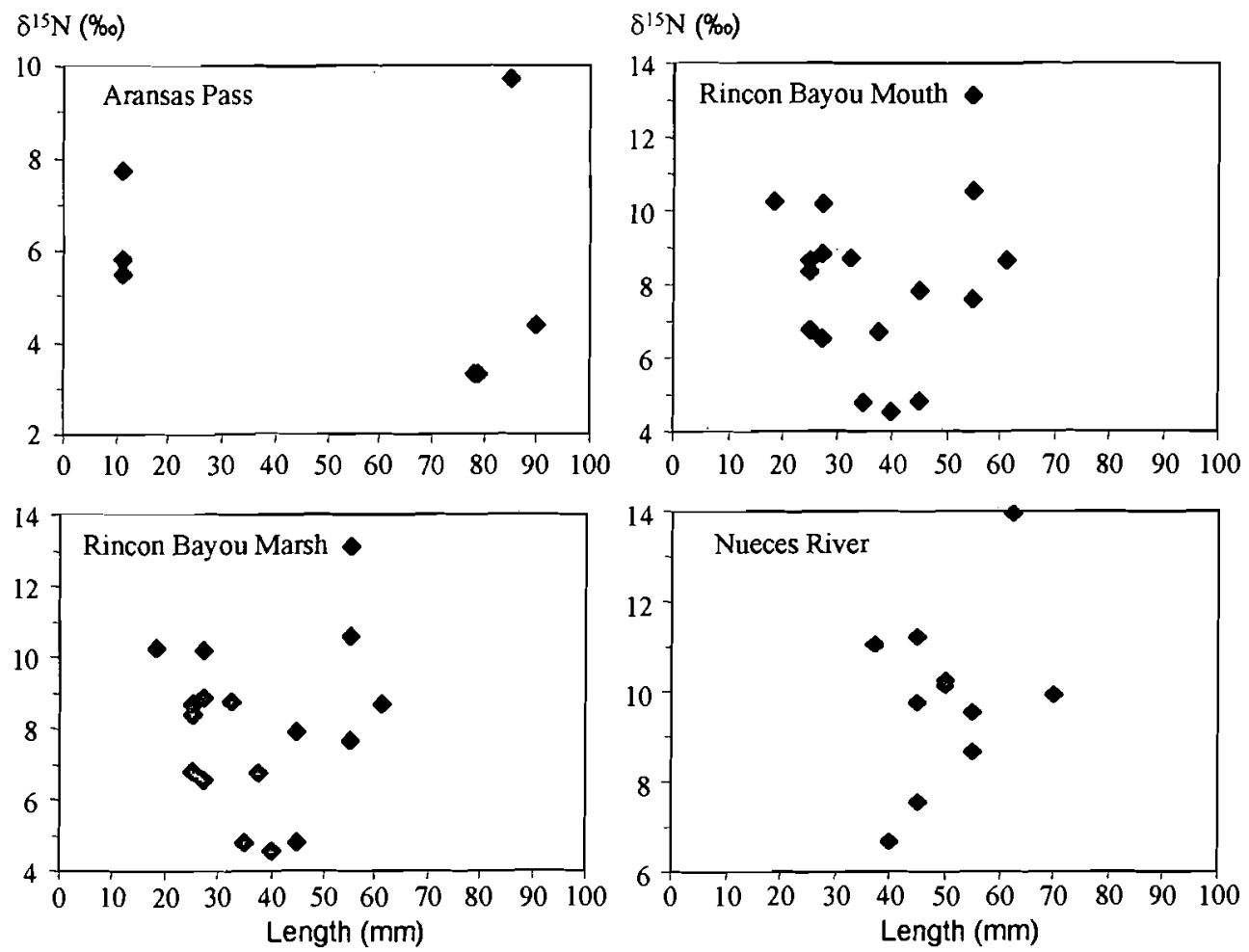

Fig. 4. Relation between $\delta^{15} \mathrm{~N}$ and size length of brown shrimp Penaeus aztecus between Aransas Pass and Nueces River from January 1996 to July 1996 
of $P$. aztecus throughout its growth and migration are not associated with an increase in trophic level with size but mostly related to feeding habitats, as indicated by $\delta^{13} \mathrm{C}$.

In addition, large ranges of $\delta^{15} \mathrm{~N}$ observed for shrimps within the different habitats (Fig. 4) suggest that shrimps may use the different sources both directly and indirectly through predation. This hypothesis could explain a higher variability for shrimp $\delta^{15} \mathrm{~N}$ values compared to corresponding $\delta^{13} \mathrm{C}$ (Table 2) due to the higher trophic enrichment during nitrogen assimilation. Therefore, the results of the present study are consistent with an omnivore feeding mode for migratory juvenile brown shrimp. This is concordant with gut content analyses, which indicate that animal prey is part of the food ingested by Penaeus aztecus, but that there is no variation in dietary breadth and prey preference as shrimp grow (Hunter \& Feller 1987).

In conclusion, $\delta^{13} \mathrm{C}$ values suggest that the main food sources for juvenile brown shrimp Penaeus aztecus in the Rincon Bayou marsh are Spartina spp. detritus, benthic diatoms and blue green algae. Tissue turnover rates in these marsh habitats are apparently high, because shrimp isotopic signatures change rapidly. Moreover, $\delta^{13} \mathrm{C}$ and $\delta^{15} \mathrm{~N}$ results show that terrestrial inputs carried by the freshwater inflow can contribute significantly to the diet of juvenile brown shrimp in the Nueces River. Finally, these results show that the restoration of coastal marshes through the introduction of freshwater inflow can provide nursery areas favorable for feeding and growth of juvenile brown shrimp.

Acknowledgements. Funding for this project was provided in part by the US Bureau of Reclamation (Grant No. 4-FG-6004370) and the Texas Water Development Board (Research \& Planning Fund Contract No. 94-483-046) to The University of Texas at Austin, Marine Science Institute.

\section{LITERATURE CITED}

Anderson RK, Parker PL, Lawrence A (1987) $\mathrm{A}{ }^{13} \mathrm{C} /{ }^{12} \mathrm{C}$ tracer study of the utilization of presented feed by a commercially important shrimp Peneaus vannamei in a pond growout system. J Wildl Aquacult Soc 18:148-155

Bayne BL, Hawkins AJS, Navarro E (1987) Feeding and digestion by the mussel Mytilus edulis L. (Bivalvia: Mollusca) in mixtures of silt and algal cells at low concentrations. J Exp Mar Biol Ecol 111:1-22

Boutton TW (1991) Stable carbon isotope ratios of natural materials: I. Sample preparation and mass spectrometric analysis. In: Coleman DC, Fry B (eds) Carbon isotopes techniques. Academic Press Inc, San Diego, p 155-171

Calder JA, Parker PL (1973) Geochemical implications of induced changes in ${ }^{13} \mathrm{C}$ fractionation by blue-green algae. Geochim Cosmochim Acta 37:141-154

Chong VC, Sasekumar A (1981) Food and feeding habits of the white prawn Penaeus merguiensis. Mar Ecol Prog Ser $5: 185-191$
Couch CA (1989) Carbon and nitrogen stable isotopes of meiobenthos and their food resources. Estuar Coast Shelf Sci 28:433-441

Créach V, Schricke MT, Bertru G, Mariotti A (1997) Stable isotopes and gut analyses to determine feeding relationships in saltmarsh macroconsumers. Estuar Coast Shelf Sci 44:599-611

Crosby MP (1985) The use of a rapid radiolabeling method for measuring ingestion rates of detritivores. J Exp Mar Biol Ecol 93:273-283

Crosby MP, Langdon CJ, Newell RIE (1989) Importance of refractory plant material to the carbon budget of the oyster Crassostrea virginica. Mar Biol 100:343-352

Crosby MP, Newell RIE, Langdon CJ (1990) Bacterial mediation in the utilization of carbon and nitrogen from detrital complexes by Crassostrea virginica. Limnol Oceanogr 35: $625-639$

Currin CA, Newell SY, Paerl HW (1995) The role of standing dead Spartina alterniflora and benthic microalgae in salt marsh food webs: considerations based on multiple stable isotope analysis. Mar Ecol Prog Ser 121:99-116

Dall W, Hill BJ, Rothlisberg PC, Staples DJ ( 1990) The biology of the Penaeidae. In: Blaxter JHS, Southward AJ (eds) Adv Mar Biol 27:1-489

Day JW, Hall CAS, Kemp WM, Yanez-Arancibia A (1989) Estuarine ecology. John Wiley \& Sons, New York

Deegan LA, Garritt RH (1997) Evidence for spatial variability in estuarine food webs. Mar Ecol Prog Ser 147:31-47

Degens ET (1969) Biogeochemistry of stable carbon isotopes. In: Eglington G, Murphy MTJ (eds) Organic geochemistry: methods and results. Springer, New York, p 304-329

DeNiro MJ, Epstein S (1978) Influence of diet on the distribution of carbone isotopes in animals. Geochim Cosmochim Acta 42:495-506

Fry B (1981) Natural stable carbon isotope tag traces Texas shrimp migrations. Fish Bull 79:337-345

Fry B (1988) Food web structure on Georges Bank from stable C, N, and S isotopic compositions. Limnol Oceanogr 33: $1182-1190$

Fry B, Arnold C (1982) Rapid ${ }^{13} \mathrm{C} /{ }^{12} \mathrm{C}$ turnover during growth of brown shrimp (Penaeus aztecus). Oecologia (Berlin) 54:200-204

Fry B, Parker PL (1979) Animal diet in Texas seagrass meadows: $\delta^{13} \mathrm{C}$ evidence for the importance of benthic plants. Estuar Coast Mar Sci 8:499-509

Fry B, Sherr EB (1984) $\delta^{13} \mathrm{C}$ measurements as indicators of carbon flow in marine and freshwater ecosystems. Contrib Mar Sci 27:13-47

Gleason DF (1986) Utilization of salt marsh plants by postlarval brown shrimp: carbon assimilation rates and food preferences. Mar Ecol Prog Ser 31:151-158

Gleason DF, Wellington GM (1988) Food resources of postlarval brown shrimp (Penaeus aztecus) in a Texas salt marsh. Mar Biol 97:329-337

Gleason DF, Zimmerman RJ (1984) Herbivory potential of postlarval brown shrimp associated with salt marshes. J Expl Mar Biol Ecol 84:235-246

Hackney CT, Haines EB (1980) Stable carbon isotope composition of fauna and organic matter collected in a Mississippi estuary. Estuar Coast Mar Sci 10:703-708

Harrigan P, Zieman JC, Macko SA (1989) The base of nutritional support for the gray snapper (Lutjanus griseus): an evaluation based on a combined stomach content and stable isotope analysis. Bull Mar Sci 44:65-77

Heales DS, Vance DJ, Loneragan NR (1996) Field observations of moult cycle, feeding behaviour, and diet of small 
juvenile tiger prawns Penaeus semisulcatus in the Embley River, Australia. Mar Ecol Prog.Ser 145:43-51

Hedges JI, Clark WA, Quay PD, Richey JE, Devol AH, de M Santos U (1986) Compositions and fluxes of particulate organic material in the Amazon River. Limnol Oceanogr $31: 717-738$

Hughes EH, Sherr EB (1983) Subtidal food webs in a Georgia estuary: $\delta^{13} \mathrm{C}$ analysis. J Exp Mar Biol Ecol 67:227-242

Hunter J, Feller RJ (1987) Immunological dietary analysis of two penaeid shrimp species from a South Carolina tidal creek. J Exp Mar Biol Ecol 107:61-70

Incze LS, Mayer LM, Sherr EB, Macko SA (1982) Carbon inputs to bivalve mollusks: a comparison of two estuaries. Can J Fish Aquat Sci 39:1348-1352

Langdon CJ, Newell RIE (1990) Utilization of detritus and bacteria as food sources by two bivalve suspension-feeders, the oyster Crassostrea virginica and the mussel Geukensia demissa. Mar Ecol Prog Ser 58:299-310

Macko SA, Lee WY, Parker PL (1982) Nitrogen and carbon isotope fractionation by two species of marine amphipods: laboratory and field studies. J Exp Mar Biol Ecol 63: $145-149$

Mariotti A (1982) Apports de la géochimie isotopique à la connaissance du cycle de l'azote. Th Etat Sci, University of Paris

Minagawa M, Wada E (1984) Stepwise enrichment of ${ }^{15} \mathrm{~N}$ along food chains: further evidence and the relation between $\delta^{15} \mathrm{~N}$ and animal age. Geochim Cosmochim Acta 48:1135-1140

Moffett AW (1970) The shrimp fishery in Texas. Texas Parks and Wildlife Department, Austin

Newell RIE, Marshall N, Sasekumar A, Chong VC (1995) Relative importance of benthic microalgae, phytoplankton, and mangroves as sources of nutrition for penaeid prawns and other coastal invertebrates from Malaysia. Mar Biol 123:595-606

Nixon SA, Oviatt CA, Frithsen J, Sullivan B (1986) Nutrients and the productivity of estuarine and coastal marine ecosystems. J Limnol Soc Sth Afr 12:43-71

Parker PL, Anderson RK, Lawrence A (1988) A $\delta^{13} \mathrm{C}$ and $\delta^{15} \mathrm{~N}$ tracer study of nutrition in aquaculture: Penaeus vannamei in a pond growout system. In: Rundel PW,

Editorial responsibility: Colin Levings (Contributing Editor), West Vancouver, British Columbia, Canada
Ehleringer JR, Nagy KA (eds) Stable isotopes in ecological research. Springer-Verlag, New York

Rau GH (1978) Carbon-13 depletion in a subalpine lake: carbon flow implications. Science 201:901-902

Rau GH, Mearns AJ, Young DR, Olson RJ, Schafer HA Kaplan IR (1983) Animal ${ }^{13} \mathrm{C}^{12} \mathrm{C}$ correlates with trophic level in pelagic food webs. Ecology 64:1314-1318

Riera P, Richard P (1996) Isotopic determination of food sources of Crassostrea gigas along a trophic gradient in the estuarine bay of Marennies-Oléron. Estuar Coast Shelf Sci 42:347-360

Riera P, Richard P (1997) Temporal variation of delta ${ }^{13} \mathrm{C}$ in particulate organic matter and oyster Crassostrea gigas in Marennes-Oléron Bay (France): effect of freshwater inflow. Mar Ecol Prog Ser 147:105-115

Staples DJ (1980) Ecology of juvenile and adolescent banana prawns, Penaeus merguiensis, in a mangrove estuary and adjacent off-shore area of the Gulf of Carpentaria. I. Immigration and settlement of postlarvae. Aust J Mar Freshw Res 31:635-652

Stephenson RL, Lyon GL (1982) Carbon-13 depletion in an estuarine Bivalve: Detection of marine and terrestrial food sources. Oecologia 55:110-113

Stoner AW, Zimmerman RJ (1988) Food pathways associated with penaeid shrimps in a mangrove-fringed estuary. Fish Bull 86:543-551

Street GT, Montagna PA, Parker PL (1997) Incorporation of brown tide into an estuarine food web. Mar Ecol Prog Ser 152:67-78

Stump RK, Frazer JW (1973) Simultaneous determination of carbon, hydrogen and nitrogen in organic compounds. Report UCID 16198, Lawrence Livermore National Laboratory, University of California, Berkeley

Thayer GW, Govoni JJ, Connally DW (1983) Stable carbon isotope ratios of the planktonic food web in the northern Gulf of Mexico. Bull Mar Sci 33:247-256

Wassenberg TJ, Hill BJ (1987) Natural diet of the tiger prawns Penaeus esculentus and P. semisulcatus. Aust $\mathrm{J}$ Mar Freshw Res 38:169-182

Zein-Eldin ZP, Aldrich DV (1965) Growth and survival of postlarval Penaeus aztecus under controlled conditions of temperature and salinity. Biol Bull 129:199-216

Submitted: November 16, 1997; Accepted: November 23, 1999 Proofs received from author(s): May 31, 2000 